\title{
HASIL BELAJAR SISWA BERDASARKAN GAYA BELAJAR YANG DIAJAR DENGAN MODEL PEMBELAJARAN VISUAL, AUDITORI, DAN KINESTETIK PADA MATERI LARUTAN ELEKTROLIT DAN NON ELEKTROLIT \\ STUDENTS' LEARNING OUTCOME BASED ON LEARNING STYLE TAUGHT USING VISUAL, AUDITORY AND KINESTHETIC LEARNING MODEL ON THE SUBJECT OF ELECTROLYTES AND NONELECTROLYTES SOLUTION
}

\author{
Refka Revina Melyata Ekwanda ${ }^{1 *}$, Nurlaili ${ }^{1,2}$, Muflihah $^{1}$ \\ ${ }^{I}$ Program Studi Sarjana Pendidikan Kimia, Fakultas Keguruan dan Ilmu Pendidikan, Universitas Mulawarman \\ Samarinda, Kalimantan Timur, Indonesia \\ ${ }^{2}$ Program Magister Manajemen Pendidikan, Fakultas Keguruan dan Ilmu Pendidikan, Universitas \\ Mulawarman, Samarinda, Kalimantan Timur, Indonesia \\ *Corresponding Author: refkareviname@gmail.com
}

\begin{abstract}
ABSTRAK
Penelitian ini bertujuan untuk mengetahui peningkatan hasil belajar siswa berdasarkan gaya belajar yang diajar dengan model pembelajaran visual, auditori, dan kinestetik (VAK) pada pokok bahasan larutan elektrolit dan nonelektrolit di SMA Negeri 4 Samarinda tahun ajaran 2018/2019. Sampel dalam penelitian adalah 70 siswa kelas X IPA dipilih secara purposive sampling. Penelitian ini menggunakan desain penelitian one group pretest-posttest design. Gaya belajar siswa diperoleh menggunakan angket dan hasil belajar siswa diperoleh menggunakan tes tertulis. Peningkatan hasil belajar siswa dianalisis dengan menggunakan nilai $N$-gain Hasil penelitian menunjukkan bahwa siswa dengan gaya belajar visual, auditori dan kinestetik masing-masing 23, 22, dan 25 siswa. Nilai rata-rata $N$-gain siswa dengan gaya belajar visual, auditori, dan kinestetik, masing-masing adalah 0,56, 0,62 dan 0,56 yang semuanya termasuk dalam kategori sedang. Penelitian ini menunjukkan bahwa peningkatan hasil belajar siswa yang memiliki gaya belajar auditori lebih tinggi dibandingkan siswa yang memiliki gaya belajar visual dan kinestetik.
\end{abstract}

Kata kunci: gaya belajar, VAK, hasil belajar

\begin{abstract}
This study aimed to determine an increment of students' learning outcomes based on learning styles taugh using visual, auditory an kinesthetic (VAK) learning model on the subject of electrolytes and nonelectrolytes solution at SMA Negeri 4 Samarinda in the academic year 2018/2019. Sample in this study were 70 of tenth grade natural science students who selected by using purposive sanpling technique. This research was using one group pretest-posttest design. The tudents' learning styles were carried out using questinairre and the students' learning outcomes were collected by using written tests. An increament of the students' learning outcomes were analyzed by using N-gain score. The result of the study shows that tudents who has visual, uditory and kinesthetic learning styles were 23, 22, and 25 students, respectively. Average of $\mathrm{N}$-gain score of students who has visual, uditory and kinesthetic learning styles were $0.56,0.62$ and 0.56 , respectively, where categorized as medium. This research shows that the increment of the students learning outcomes that has auditory learning style was higher than that of students who has visual and kinesthetic learning styles.
\end{abstract}

Keywords: learning styles, VAK, learning outcome 


\section{PENDAHULUAN}

Pembelajaran yang tidak sesuai dengan gaya belajar siswa dapat mempengaruhi hasil belajarnya. Gaya belajar merupakan kombinasi dari cara siswa menyerap, mengatur, dan mengolah informasi (Deporter \& Hernick, 2003). Gaya belajar menunjukkan cara tercepat dan terbaik bagi setiap individu untuk bisa menyerap informasi dari luar dirinya. Siswa dapat mengoptimalkan hasil belajar mereka, apabila belajar sesuai dengan gaya belajarnya (Rose \& Nicholl, 1997). Siswa yang memiliki gaya belajar visual belajar dengan cara melihat, mengamati, memandang. Siswa yang memiliki gaya belajar auditori belajar dengan cara mendengar. Siswa yang memiliki gaya belajar kinestetik belajar dengan cara bergerak, bekerja dan menyentuh. Beberapa penelitian dilaporkan bahwa hasil belajar siswa dipengaruhi oleh gaya belajarnya (Indrawan, 2013; Ludjie, 2014).

Gaya balajar siswa yang bervariasi mempengaruhi cara mengajar guru dalam menyampaikan materi pelajaran. Model pembelajaran VAK (visual, auditori, kinestetik) dapat mengakomodasi kecendrungan gaya belajar siswa yang berbeda-beda. Model ini melibatkan siswa secara aktif, pembelajaran difokuskan pada pemberian pengalaman belajar secara langsung (direct experience) dan menyenangkan dengan cara belajar dengan mengingat/visual, belajar dengan mendengar/auditori dan belajar dengan bergerak /kinestetik (Rahmawati, 2011). Inayati, dkk. (2012) melaporkan bahwa pembelajaran dengan model VAK pada materi larutan elektrolit dan nonelektrolit berpengaruh pada hasil belajar sebesar 35,13\%.

Penelitian ini dirancang untuk menganalisis peningkatan hasil belajar siswa berdasarkan gaya belajar yang diajar dengan model pembelajaran VAK pada materi larutan elektrolit dan nonelektrolit.

Tabel 4.1

Data gaya belajar sampel penelitian

\begin{tabular}{lcc}
\hline Gaya Belajar & Frekuensi (n) & Persentase $\mathbf{( \% )}$ \\
\hline Visual & 23 & 32,86 \\
Auditori & 22 & 31,43 \\
Kinestetik & 25 & 35,71 \\
\hline Total & 70 & 100,0 \\
\hline
\end{tabular}

Tabel 4.2

Rata-rata $N$-gain hasil belajar siswa berdasarkan gaya belajar

\begin{tabular}{lcc}
\hline Gaya Belajar & Rata-rata $\boldsymbol{N}$-gain & Kriteria \\
\hline Visual & 0,56 & Sedang \\
Auditori & 0,62 & Sedang \\
Kinestetik & 0,56 & Sedang \\
\hline
\end{tabular}

\section{METODE PENELITIAN}

Penelitian dilaksnakan di SMA N 4 Samarinda. Sampel penelitian adalah 70 siswa kelas X IPA yang dipilih secara purposive sampling. Sampel berasal dari siswa kelas X-IPA 1 dan kelas X IPA 4. Penelitian ini menggunakan one group pretestposttest design. Pre-test dan post-test diberikan diberikan kepada sampel sebelum dan sesudah pembelajaran. Nilai tersebut yang digunakan dalam perhitungan hasil belajar dan peningkatan hasil belajar siswa menggunakan $\mathrm{N}$-gain score (Hake, 1999). Gaya belajar siswa diperoleh menggunakan angket. Peningkatan hasil belajar diperoleh dari nilai pre-test dan post-test. Selama proses pembelajaran, aktivitas siswa dan guru terus dipantau.

\section{HASIL DAN PEMBAHASAN}

Data gaya belajar siswa yang digunakan dalam sebagai sampel dalam penelitian ini disajikan dalam tabel 4.1. Rata-rata $\mathrm{N}$-gain hasil belajar siswa berdasarkan gaya belajar disajikan pada tabel 4.2. Terdapat empat langkah dalam kegiatan pembelajaran ini yaitu persiapan atau pendahuluan, penyampaian atau kegiatan inti, pelatihan dan penampilan hasil atau penutup. Proses pembelajaran menggunakan model pembelajaran VAK banyak menampilkan visualisasi. Hampir semua tahap pembelajaran ini memunculkan visualisasi materi selama proses pembelajaran.

Pada tahap persiapan, guru menampilkan gambar ilustrasi berupa banjir yang dikaitkan dengan materi larutan elektrolit dan nonelektrolit. Pada tahap penyampaian atau kegiatan inti, siswa melakukan kegiatan praktikum yaitu, menentukan larutan elektrolit dan nonelektrolit melalui praktikum. Saat praktikum siswa dapat mengamati dengan melihat secara langsung perubahan apa saja yang terjadi selama percobaan. Pada tahap pelatihan, siswa berkerjasama dalam menyelesaikan soal-soal di LKS yang telah diberikan. Pada tahap penampilan hasil atau penutup, siswa menampilkan hasil diskusi dengan kelompoknya. 
Peningkatan hasil belajar siswa terjadi karena guru mampu mengakomodir seluruh gaya belajar pada proses pembelajaran yaitu dengan menampilkan gambar untuk siswa dengan gaya belajar visual, menampilkan video untuk siswa dengan gaya belajar auditori, dan melakukan praktikum untuk siswa dengan gaya belajar kinestetik. Siswa dengan gaya belajar auditori memperoleh rata-rata $\mathrm{N}$-gain tertinggi karena siswa dengan gaya belajar auditori cenderung aktif dalam bertanya dan melakukan diskusi pada tahap kegiatan inti.

Menurut Rose dan Nicholl (2002) siswa dapat mengoptimalkan hasil belajar mereka, apabila siswa tersebut dapat belajar sesuai dengan modalitas belajarnya. Sejalan dengan penelitian Khoeron, dkk. (2014) menyatakan bahwa gaya belajar mempunyai kontribusi sebesar $52 \%$ terhadap prestasi belajar peserta didik.

\section{SIMPULAN}

Penggunaan model pembelajaran VAK pada materi larutan elektrolit dan nonelektrolit dapat meningkatkan hasil belajar semua siswa yang memiliki gaya beajar auditori, visual dan kinestetik.

\section{UCAPAN TERIMAKASIH}

Penulis mengucapkan terimakasih kepada kepala SMA Negeri 4 Samarinda, bapak Wasis, M.Pd. dan ibu Eliyati, S.Pd .yang memberikan izin dan membantu selama penelitian berlangsung.

\section{DAFTAR PUSTAKA}

Deporter, B., dan Hernacki, M. 2003. Quatum learning: membiasakan belajar nyaman dan menyenangkan. Bandung: Kaifa Learning.

Hake, R. 1999. Analyzing change/gain score. American Education Research Association's Devision.

Inayati, I., Subroto T., Supardi, K.I., 2012. Pembelajaran visualisasi, auditori, kinestetik menggunakan media swishmax materi larutan elektrolit dan nonelektrolit. Chemistry in Education, 2(1), 35-41.

Indrawan, D. 2013. Pengaruh gaya belajar terhadap hasil belajar siswa kelas IV SD Negeri panjang 3 Surakarta. Jurnal Edukasi, 1(3), 1-13.

Khoeron, I.R., Sumarna, N., dan Permana, T. 2014. Pengaruh gaya belajar terhadap prestasi belajar peserta didik pada mata pelajaran produktif. Journal of Mechanical Engineering Education. 1(2). 291-297.

Ludjie, B. A. 2014. Pengaruh gaya belajar visual, auditori, dan kinestetik terhadap prestasi belajar siswa. Jurnal Kependidikan, 44(2), 168-174.

Rahmawati, S. 2011. Penerapan model pembelajaran VAK (visual, auditori, dan kinestetik) berbasis open-ended problem untuk meningkatkan kemampuan berpikir kreatif matematis siswa. Skripsi. Bandung: Universitas Pendidikan Indonesia.

Rose dan Nicholl, J. 1997. Accelerated learning for the 21 st century: cara belajar cepat abad 21. Bandung: Nuansa. 